Vol. XXV No 2019

\title{
APPEAL OF PUBLIC PROCUREMENT PROCEDURES
}

\author{
Albena IVANOVA \\ "Neofit Rilski" South-West University, Blagoevgrad, Bulgaria \\ lexa777@abv.bg
}

\begin{abstract}
Public Procurement is an important element of the Internal Market and a basic method of public spending and ensuring the free movement of goods, services and works by domestic and foreign companies. Through the adoption and implementation in the national legislation of the Member States of a package of Directives 2014, a new Public Procurement regime is settled. The purpose of the new Directives is to exclude the risk of giving national tenderers an advantage. There are a number of issues, including the kind of legal protection contractors can expect in Public Procurement procedures. This article analyses one of the mechanisms for controlling Public Procurement - their appeal. It relates to the judicial control exercised by the relevant national institutions in the Member States and the conditions and procedures for appeal that are governed by the national laws, once the Directives have been transposed into national legal systems. Despite a limited number of cases, the Court of Justice of EU (CJEU) also exercises judicial review within the context of a reference for a preliminary ruling, where a national court hearing an appeal against a Public Procurement procedure, has referred a question to the CJEU.
\end{abstract}

Keywords: Public Procurement, appeal, national courts, Court of Justice of EU.

\section{Introduction}

A new package of Public Procurement of Directives is adopted in 2014 - Directive 2014/23/EU on the award of concession contracts; Directive 2014/24/EU on Public Procurement; Directive 2014/25 on the procurement of contracting entities operating in the water, energy, transport and postal services sectors. The new directives entered into force on 17 April 2014 and set a deadline of 18 April 2016 to be transposed by all Member States of the European Union into their national legislation.

Public Procurement Directives determine the award procedures and certain specificities of the performance of Public Procurement and concession contracts above certain thresholds.

The choice of proportionate, non- discriminatory and fair selection criteria and their application to economic operators is crucial and is one of the main objectives for the effective access of operators to economic opportunities related to public procurement and concessions. These criteria in the recent past of Bulgaria and the other countries of Eastern Europe were not particularly respected. In the last twenty years, there has been a significant evolution of the Bulgarian citizens' attitude with regard to protection of their human and economic rights and of rights of others [1]. The clarity and reliability of information on Public Procurement are important for the transparency of procurement criteria and procedures. In their description, there should not be misleading information contained in it. These requirements are to a 
lesser extent related to the increasingly topical issue of fake news. They use methods by using different techniques that give the search result as in political campaigns, and in business models for profit [2]. Easy access to relevant tools highlights almost complete lack of obstacles, which in the field of Public Procurement by elaborating misleading criteria leads to violation of the rights of the participants, respectively to appealing the procedure.

There are two peculiarities in litigation for damages in Public Procurement. One relates to the fact that the entities involved in the procurement procedure, in view of the fact that they will deteriorate their relations with the contracting authority and which would cause them difficulties in the future, will not complain to the competent court in some cases of violations. The dispute between a supplier and a contracting authority often leads to the irreversible destruction of their relationship. The other is related to the number of benefits. If they are too large and too easy to award, contracting authorities will find incentives in subsequent auctions to find incentives to hinder the public service or supply contract with the benefit provider. To a large extent, this depends on the practice of national courts in various specific cases [3].

In order to meet the objectives of Public Procurement law, the legal remedies were introduced in addition to the first Acts in this area as accompanying measures Directives 89/665 / EEC and 92/13 / EEC, as amended by Directive 2007/66 / EC4.

These Directives were intended, by setting minimum Community (EC) standards for control and the possibility of appealing procedures, to ensure economic operators that they will have access to fast and efficient procedures throughout the EU. The Directive 89/665, which refers to the remedies, including the appeal, states in Article 2 (1) that Member States shall ensure that the measures adopted on appeal procedures permit: (a) to adopt interim measures, in order to remedy an alleged infringement; to prevent further damage to the interests involved; (b) to cancel, or to revoke unlawful decisions, i.e. discriminatory, technical, economic or financial specifications attached to the invitation to tender in the contract documents, or in any other document relating to the award procedure of the order; to compensate the persons harmed by an infringement. The Directive has overridden those powers to be made available to separate national bodies, responsible for various aspects of the appeal procedure.

At present, Directives 89/665/EEC and 92/13/EEC have been amended in Articles 46 and 47 of Directive 2014/23, which makes them the currently applicable law on Public Procurement issues.

The Directives provide for Member States to set up judicial or administrative bodies responsible for their implementation. However, Member States have a choice regarding the forum and the procedures provided for hearing disputes or achieving the desired result. They also require that all decisions taken by the authorities responsible for review procedures are effectively aligned.

Member States have adopted national rules having a different scope and nature in view of their respective legal traditions, relying on the minimum harmonization of remedies provided by the directives.

Various reviewing bodies have been set up in each Member State. In 14 Member States, including Bulgaria and Romania, there is an administrative review body (specialized or not) in the field of Public Procurement. In the other Member States, there is a judicial authority responsible for reviewing Public Procurement procedures [4]. In Bulgaria, the Supreme Administrative Court acts only as a cassation instance.

The appeal of Public Procurement is most often done before the national courts of Member States especially in cases where damages are claimed for damages suffered by contractors' violations. Also, appeals are 
often brought before the General Court (GC), whose decisions are appealed before the Court of Justice of EU (CJEU).

\section{Appeal and national jurisdictions}

In the field of Public Procurement, individuals, as main subjects, in their capacity as contractors, should have the opportunity, within wide limits, to protect their rights in cases of breached procedures. An important prerequisite for this is the access to justice, which is achieved through appeal, which, in most cases, is a mechanism for judicial control at the national level.

It has been established that all Member States require review procedures to be available to every person who has or has had an interest in winning a contract and who has been or could be harmed by an alleged infringement.

Similarly, all Member States provide for automatic notification to the participants the tendering procedure why they did not win after the award decision order [5]. In this connection, it is the introduction of the electronic exchange of information and documents in the field of Public Procurement. The conditions are therefore created by specialized laws in some Member States.

Electronic means of information and communication can greatly simplify the publication of Public Procurement and concessions and increase the efficiency, speed and transparency of Procurement processes, making their use very important. In Bulgaria, the Electronic Document and Electronic Signature Act recognizes electronic documents equivalent to those of paper and can be signed with a simple, sophisticated or qualified electronic signature which has legal significance for a handwritten signature. A Law on Electronic Governance regulates the activity of the administrative bodies in working with electronic documents, the provision of electronic administrative services and the exchange of electronic documents between the administrative bodies [6]. They are quite widely used in the field of Public Procurement, unlike other administrativelegal branches, where their arrangements are not exhaustive.

National courts usually have both the power to rule on damages, including those arising from the breach of Public Procurement procedures, and the means to enforce their decisions. In most cases, the administrative body cannot ensure the effective implementation of its decisions without judicial intervention. In case of arbitration, the winning party in order to execute the arbitration award (in some countries this option is provided) must turn to the national courts and ask for an enforcement order or an order for the relevant cases to be executed[7]. The appeal of a contracting authority's decision to a competent national court is the only option in some Member States. In others, as under the Bulgarian Law on Public Procurement, it is envisaged to appeal first to a special jurisdiction, such as the Commission for Protection Against Competition in Bulgaria or an administrative body, and their decisions may be appealed before a court. The conditions and procedures for appeal are governed by the national laws, once the Remedies Directives have been transposed into national legal systems. The Bulgarian Public Procurement Act (Prom. SG. issue 13 of February 16, 2016, suppl. SG. issue 34 of 3 May 2016, amend. and suppl. SG. No. 63 of 4 August 2017, last suppl. SG. 17 of 26 of February 2019) in articles in Chapter 27 "Appeal procedures" provides rules and determine exactly which decisions, actions and omissions of contractors are subject to appeal before the Commission for Protection of Competition at first instance and the Supreme Administrative Court is a cassation instance in the appeal [8]. The decisions and judgments of the court are final. The Act specifies precisely which decisions of contracting authorities are subject to review of legality, which of them are explicitly 
excluded from the possibility of appeal, determines the time limits in which the complaints and their requisites are filed, who may be the complainant, the rules under which the cases are dealt, the imposition of provisional measures and the admission of prior enforcement of the contracting authority's decisions.

Particular attention is paid to the circle of persons entitled to appeal. Article 198 of the Act defines as interested several groups of persons, including any interested person - in the cases under Art. 197, §1, items 1-5 and 8 and $\S 2$; any interested candidate in the procedure - in the cases under Art. 197 $\S 1$, items 2, 6 and 7 and $\S .2 ; 3$. any interested candidate or participant - in the cases under Art. 197 §. 1, items 5 and 7 and $\S .2$, as well as the professional associations and organizations regulated in art. 197, § 2 for protection of the interests of their members against the decision to initiate the procedure and the decision for approval of changes in the conditions under a proclaimed procedure. The Public Procurement Act determines various kind of interested parties by giving a legal definition of the concepts in Other Provisions of the Act, such as "Interested Applicant" (candidate who has not been finally removed from the pre-selection phase because he is not notified of the removal or appeal proceedings, the decision with which it was removed is not over); "Interested Participant" (participant that is not permanently removed from the Procedure. An interested participant is also a participant who is rated but not selected as a contractor); and "Interested party" (any person who has or has had an interest in obtaining a particular contract and has been or may be harmed by the alleged infringement). The legislator wanted to make clear and have no doubt what the persons with active procedural legitimacy in the appeals cases do. To a great extent, the approach in the law reflects legal concept according to which the concept of 'interested party' constitutes substantive quality of the subjects of the law which arises in all cases where the act, or omission of the administrative authorities happens.

It brings about a change in their legal sphere. The quality "interested" by the legal effect of a specific administrative act, which is undoubtedly the acts of the contracting authorities, their unlawful acts or omissions, occurs irrespective of the type of consequences [9].

\section{Case law in CJEU practice}

When primary and secondary legislation of the European Union is directly applicable and directly effective, the national courts of the Member States may claim jurisdiction in the event of a Member State failing to fulfil its obligations. Individuals can also rely on and enjoy remedies before national courts by referring to the provisions of the European Union law that have a direct effect. With regard to the Public Procurement directives, actions can be triggered from individuals against the State, the central government, the local authorities and the contracting authorities, provided that certain provisions of the directives on which individuals rely produce a direct impact. In its long-standing practice, the Court finds it competent to rule on the acts of EU bodies, offices and agencies which are empowered to adopt legally binding measures for individuals in specific areas, including those intended to produce legal effects vis-à-vis third parties, such as judicial review mechanisms. (C-562/12 - Liivimaa Lihaveis, p.46, ECLI:EU:C:2014:2229; C-270/12-United Kingdom $v$ Council and Parliament, EU:C:2014:18, p. 81).

Although the regulation of the appeal, following the transposition of the relevant directives in the Member States, is left to their national laws, in a limited number of cases, the CJEU also exercises judicial review within the context of a reference for a preliminary ruling. When a question concerning the interpretation of EU Treaties and the validity and interpretation of acts of 
the European Union's institutions, bodies, offices or agencies is brought before a court in a Member State, that court may ask the CJEU for a preliminary ruling, if considered necessary. The same rules are reproduced in Article 628 of the Bulgarian Civil Procedure Code [10]. The judicial review by CJEU in the aforementioned restricted number of cases is realized within the reference for a preliminary ruling. In Case C-391/15-Marina del Mediterráneo SL and others, ECLI:EU:C:2017:268, on the reference for a preliminary ruling concerning the interpretation of Articles 1 (1) and 2 (1) of Directive 89/665 / EEC on the coordination of laws, regulations and administrative provisions, the Court held that "Article 1 (1) and Article 2 (1) (a) and (b) of Directive $89 / 665 /$ EEC must be interpreted as precluding an application for a review of a contract for the award of public works contracts, to be interpreted as precluding, in a situation such as that at issue in the main proceedings, national legislation according to which the decision to admit a tenderer in a contract award procedure which is alleged to be in breach of European Union law on Public Procurement or its transposing national legislation - is not among the preparatory acts of the contracting authority against which a separate complaint may be brought before a court." The CJEU also pointed that there has already been ruled in a previous judgment (Koppensteiner, C15/04, EU: C: 2005: 345, p.38) "that the provisions of Article 1 (1) and (1) and (b) of Article 1 (1) Article 2 of the Directive $89 / 665 /$ EEC is unconditional and sufficiently clear to create rights for the individual to whom it may rely directly against the contracting authority."

In its case law, the CJEU also concludes that when transposing directives in the field of Public Procurement Member States may, in addition to the grounds for excluding a participant from a procedure specified in the Directives, introduce additional substantive rules of national law designed to ensure greater respect for the principles of equal treatment of all tenderers and transparency that underlie EU Directives. (C-144/17 - Lloyd's of London, ECLI:EU:C:2018:78).

It should be pointed out that the majority of cases brought before national courts and later referred to the Court of Justice concern the meaning and definition of "contracting authorities" and the application of the selection and award criteria laid down in the directives on Public Procurement [11].

\section{Conclusions}

Appealing Public Procurement procedures is a complex and sensitive matter. Their rules have certain characteristics, compared to other areas of EU law, and this is reflected in the rules on appeals, which is largely left to the national jurisdictions of the Member States. This is because, on the one hand, the conditions and rules of procedures are detailed in their internal legislation by transposing the Public Procurement Directives. On the other hand, the Remedies Directives refer to them, as well as the requirements for obtaining damages as a result of infringements in the conduct of Public Procurement tenders are governed by national rules. There are a number of unclear aspects of Directives on remedies, including appeals, in order to improve the understanding and application of certain provisions and to ensure their effectiveness. Although the practice of CJEU largely interprets EU law, it is necessary to take measures for the interaction between the redress directives and the new procurement package of Directives. 


\section{References}

[1] Chankova. D., G. Georgieva, Security and Human Rights: Contradictory or Reconcilable Paradigms? State of Affairs in Bulgaria, International Conference KNOWLEDGE-BASED ORGANIZATION, Vol. XXII, No22, 2016, DOI: https://doi.org/10.1515/kbo-2016-0053;

[2] Belova. G., G. Georgieva, Fake News as a Threat to National Security, International Conference KNOWLEDGE-BASED ORGANIZATION, Vol. XXIV, No24, 2018, DOI: https://doi.org/10.1515/kbo-2018-0002;

[3] [7] [11] Bovis Chr., EC Public Procurement: Case Law and Regulation, Oxford, Oxford University Press, 2006;

[4] [5] Report from the Commission to the European Parliament and the Council on the effectiveness of Directive 89/665/EEC and Directive 92/13/EEC, as modified by Directive 2007/66/EC, concerning review procedures in the area of public procurement, COM/2017/028final, https://eur-lex.europa.eu/legal-content/EN/TXT/?uri=COM:2017:28:FIN

[6] Aleksandrova, V., Legal aspects of electronic communication and its proof according to the tax and social insurance procedure code regulations, International Conference KNOWLEDGE-BASED ORGANIZATION, Vol. XXIV, No24, 2018, DOI: 10.1515/kbo-2018-0079

[8] Markov M., E. Dimova, A. Aleksandrov, M. Katzarova M., The new legal framework for public procurement and the management of European funds, 2016, in Bulgarian, Sofia, Trud i Pravo;

Марков М., Е. Димова, А. Александров, М. Кацарова, Новият правен режим на обществените поръчки и управлението на европейските фондове, 2016, София, ИК “Труд и право“;

[9] Kanatova-Buchkova V., The interested parties under the Administrative Procedure Code, 2015, in Bulgarian, Sofia, Sibi;

Канатова-Бучкова, В., „Заинтересованите лица по Административнопроцесуалния кодекс", 2015, София, Сиби.

[10] Minkova G., Reference for a preliminary ruling to the Court of Justice of the European Union in tax law, mag. "Business and Law", issue 4/2019, in Bulgarian, Sofia, in print;

Минкова Г.,Преюдициални запитвания до Съда на Европейския съюз в данъчното право, сп. „Бизнес и право“, бр.4/2019, София, под печат;

See also: Tzvetanov I., Competition Policy in the European Union in the Context of the Europe 2020 Strategy, mag. Commercial and Obligatory Law, Issue 2/2013, in Bulgarian, Sofia,;

Цветанов И., "Политиката на конкуренция в Европейския съюз в контекста на Стратегия "Европа 2020", сп. Търговско и облигационно право, бр.2/2013;

Rabohchiyska M.,"The Lisbon Treaty - A Skilfully Reconstructed Constitution for Europe?", mag.International Relations, issue 4/2008, in Bulgarian, Sofia,;

Рабохчийска М., "Лисабонският договор - умело предоговорена конституция за Европа?", сп. Международни отношения. 